doi $10.15826 /$ recon.2021.7.1.003

UDC 332

JEL R58, R13, N95, P48

\title{
Regional differences in mainland China after the 1970s economic reform
}

Lu Jia Jin $\bowtie$, L.P. Piskunova

Ural Federal University, Ekaterinburg, Russia; lujiajin@yandex.ru

\begin{abstract}
Relevance. In recent years, China's GDP has continued to grow, however, the regional gap in socio-economic development is still huge. It is, therefore, crucial to investigate the reasons behind regional disparities and the possible solutions to this problem. Research objective. This paper aims to examine the patterns of regional differences in mainland China after the economic reform of the 1970s. Data and methods. The study relies on the methods of comparative analysis and the data from the National Bureau of Statistics of the People's Republic of China and the Statistical Yearbook Sharing Platform as well as the information from the national media portal - Xinhua News Agency. Results. The Chinese government's application of differentiated measures, strategies and policies to different regions exacerbated the existing disparities. This paper elaborates on the future regional economic adjustments and plans and thus can be of interest to investors and business activists in China and other countries.
\end{abstract}

\section{KEY WORDS}

Chinese economic development, regional differences, Chinese economic regions, urbanization, city clusters, city tier system

\section{FOR CITATION}

Jia Jin, Lu, \& Piskunova, L.P. (2021) Regional differences in mainland China after the 1970 s economic reform. R-economy, 7(1), 28-41. doi: 10.15826/recon.2021.7.1.003.

\section{Региональные различия в КНР после китайской экономической реформы}

\author{
Лу Цзяцзинь $\bowtie$, Л.П. Пискунова
}

Уральский федеральный университет, Екатеринбург, Россия; lujiajin@yапdех.ru

\begin{abstract}
АННОТАЦИЯ
Актуальность. В последние годы ВВП Китая продолжает расти, однако разрыв в региональном развитии по-прежнему огромен. Поэтому крайне важно исследовать причины региональных различий и возможные решения этой проблемы. Цель исследования. Целью данной статьи является исследование закономерностей региональных различий в КНР после китайской экономической реформы. Данные и методы. В основе исследования лежат методы сравнительного анализа и данные Национального статистического бюро КНР и Платформы статистических ежегодников, а также информация национального медиа-портала - агентства новостей Синьхуа. Результаты. Применение правительством Китая дифференцированных мер, стратегий и политики к различным регионам увеличило существующие различия. В этом исследовании подробно рассматриваются будущие региональные экономические изменения и планы, поэтому он может быть интересен инвесторам и бизнес-активистам Китая и других стран.
\end{abstract}

\section{КЛЮЧЕВЫЕ СЛОВА}

китайское экономическое развитие, региональные различия, китайские экономические регионы, урбанизация, городские кластеры, городская система уровней

\section{ДЛЯ ЦИТИРОВАНИЯ}

Jia Jin, Lu, \& Piskunova L.P. (2021) Regional differences in mainland China after the 1970 s economic reform. R-economy, 7(1), 28-41. doi: 10.15826/recon.2021.7.1.003.

\section{Introduction}

China is a country with significant regional differences in population, resources, economy and environmental conditions, which inevitably leads to regional differences in socio-economic development. Chinese-style urbanization is different from other countries because it is deeply influenced by geographical conditions, economic potential, and economic policy.
In 1978, China began to transform its highly centralized planned economy into a market economy. The Chinese government prioritized efficiency and proposed a hierarchical development strategy for the country's regions. China has formed 4 economic regions - East Coast, Central China, Northeast China, Western China. In the early $21^{\text {st }}$ century, due to the slow economic development in some regions, China pro- 
posed regional development strategies such as the Rise of Central China Plan, China Western Development, and Revitalization of the Old Northeast Industrial Bases.

In the last decade, many top cities and mature city clusters have appeared in eastern and central regions. Jing-Jin-Ji, the Yangzte River Delta, and Pearl River Delta will be developed as three world-class city clusters. The country also has a city tier system, which is a hierarchical classification of Chinese cities: cities in different tiers reflect differences in consumer behavior, income level, population size, consumer sophistication, infrastructure, talent pool, and business opportunity.

Regional disparities lead to regional discrimination, which sometimes even resembles nationality discrimination. In this study, our goal is to analyze the causes and processes underlying regional imbalances in mainland China as well as the resulting crises and the corresponding policy solutions. tives:

This paper focuses on the following objec-

- to analyze the relationship between geographical differences and economic potential in various regions of mainland China;

- to describe the regional development after China's economic reform in the 1970s;

- to show the current level of urbanization in various regions;

- to analyze the social crisis caused by huge differences in regional economic levels;

- to describe the economic policy adjustments in response to the social crisis.

\section{Theoretical background}

Regarding regional differences in China, significant body of research has been accumulated. At first, scholars focused on urban-rural changes and urbanization. Lin et al. (2018) demonstrated that regional differences in urbanization are significantly correlated with per capita GDP, industry location quotients, urban-rural income ratio, and time distance to major centers. Hundreds of millions of rural inhabitants have migrated to cities, which accelerated the development of cities and towns across the country.

Zang et al. (2015) discussed the relationship between rural and urban migration, the household registration system, and housing prices. Their results suggest that the rising urban hou- sing prices within the immigration areas are an important factor that can influence rural-urban migrants' settlement decision-making.

After the reform of the household registration system, the urban-rural economic gap has been narrowed, but the regional gap widened. In recent years, regional differences have become increasingly noticeable. As for regional development trends in China, Lin \& Liu (2008) carried out a study on the provincial economic gap of mainland China with the variation coefficient and Gini coefficient. They showed that the regional gap in mainland China has grown wider since the 1990s.

Zhang \& Liang (2015) contend that the unbalanced distribution of human capital in various provinces and cities is also the reason behind the continuously growing regional economic disparities. Candelaria et al. (2015) researched the most significant point of regional differences - the differences in the wage level. Their results indicate that regional wage differences are likely to persist in China for quite some time because they are influenced by long-term factors such as education, industry and geographic location.

Environmental performance also has been the focus of research in the past decades. Chen and Jia (2017) emphasized that larger differences exist in environmental efficiencies of Chinese regions. Xiao et al. (2017) analyzed the impact of innovation capital and innovation culture on regional innovation capability development.

There are many studies aiming to investigate the reasons for huge regional differences in mainland China, despite the major economic reforms. This question, however, still remains open for debate. In order to analyze the regional differences in mainland China, we should look at the dynamics of regional development, which is what we intend to do in this article.

\section{Method and Data}

The study relies on the method of comparative analysis. It compares the statistics on different parts of mainland China especially in what concerns their geographic differences, belonging to specific economic regions, the existence of city clusters and the place occupied by the cities in the city tier system. In addition, this paper traces the history of China's economic reform to reveal the reasons for the imbalance in various regions.

The rest of this paper is organized as follows. The research goes through the following five sta- 
ges. At the first stage, we analyze the geographical barriers and resource availability as the main cause of disparities between various regions of mainland China and their respective economic potentials. At the second stage, the economic development of regions after the economic reform in the 1970s is described. At the third stage, this paper shows the level of urbanization and development of mature city clusters in mainland China. At the fourth stage, the social crisis caused by regional differences is analyzed. At the final stage, the study describes the economic policy adjustments and new economic plans. For clarity, the results are displayed in the form of figures and tables.

The regional data in this paper are all publicly available; they are obtained from the National $\mathrm{Bu}$ reau of Statistics of the People's Republic of China and the Statistical Yearbook Sharing Platform ${ }^{1}$. The data on China's population, gross regional product (GRP), unemployment rate in urban areas, wage and salary income per capita, and the average regional housing prices are analyzed. In addition, the study examines the information from the official media portal - the Xinhua News Agency.

\section{Results}

One of the main causes of regional disparities in China is the geographical barriers and available resources.

Understanding the relationship between the natural environment and various cultural patterns is an essential aspect of geography. With the total area of 9,596,960 km², China features a great variety of natural conditions and landscapes. Regions have different geographical features and resources, which affects their economic potential.

The North-Eastern region has a monsoonal and continental climate. The steppe and forest occupy most of the area. In winter, it has freezing weather, the climate of some cities is similar to Novosibirsk in Russia. In this region agriculture and forestry are developed, mineral resources are abundant. The north-eastern part of the country was one of the first to industrialize in China during the era of Manchukuo ${ }^{2}$. In recent years, the region's once-abundant raw materials have depleted, however.

\footnotetext{
1 Statistical Yearbook Sharing Platform: https://www. yearbookchina.com/ is the largest free data platform for statistical yearbooks in China. (In Chinese).

2 Manchukuo, officially the State of Manchuria prior to 1934 and the Empire of Manchuria after 1934, was a puppet state of the Empire of Japan in Northeast China and Inner Mongolia from 1932 until 1945.
}

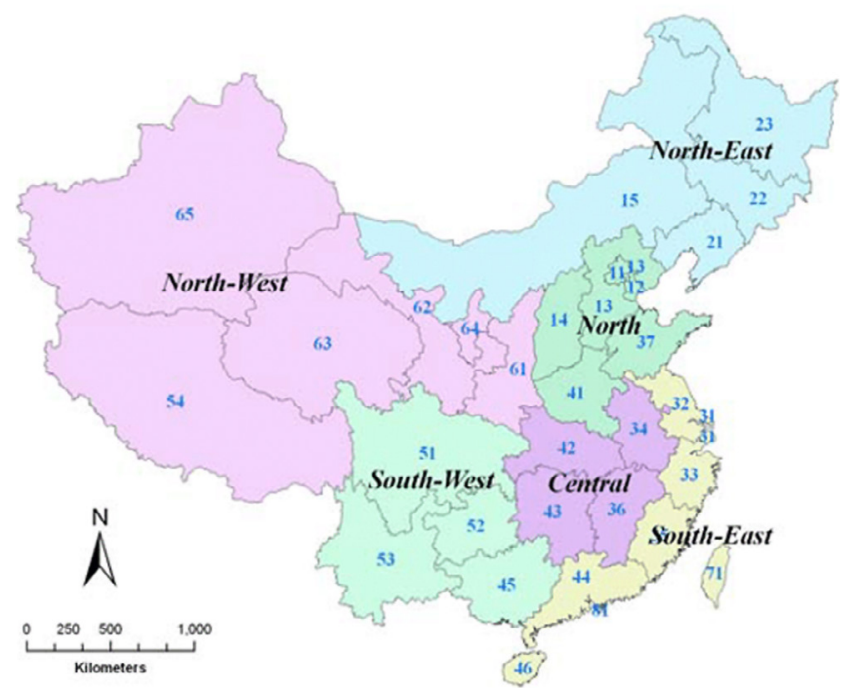

He North-Eastern region includes the following parts: 15 - Inner Mongolia, 21 - Liaoning, 22 - Jilin and

23 - Heilongjiang; North: 11 - Beijing, 12 - Tianjin, 13 - Hebei, 14 - Shanxi, 37 - Shandong and 41 - Henan; South-East: 31 - Shanghai, 32 - Jiangsu, 33 - Zhejiang, 35 - Fujian, 44 - Guangdong, 81 - Hongkong, 46 - Hainan and 71 - Taiwan;

Central: 34 - Anhui, 36-Jiangxi, 42 - Hubei and 43 - Hunan;

South-West: 45 - Guangxi, 50 - Chongqing, 51 - Sichuan,

52 - Guizhou and 53 - Yunnan; North-West: 54 - Tibet,

61 - Shannxi, 62 - Gansu, 63 - Qinghai, 64 - Ningxia and 65 - Xinjiang.

Figure 1. China's geographical regions

Source: Quantifying Urban Land Cover Dynamics and its Environmental Impacts in China Using GLCNMO Urban and Satellite Imagery, (Kasimu, Ghulam \& Tateishi, 2009).

The North-Western region is mostly desert and mountains, and is far from coastal cities, it is located high above the sea level and usually has dry weather, often suffering from the lack of rain. Mineral resources in the north-western part include coal, oil, and gas.

In ancient times, the North-West was the only road to Central Asia, West Asia, and Europe. This region was the strategic passage and communications hub of the Silk Road, also called the Ancient Tea Route. In modern times, this area has lost its role as a prosperous business center (Li \& Taube, 2019).

Most of the Northern, South-Eastern, and Central regions are close to the sea, with plenty of rain. Because of the high temperatures, in some cities, the coastal plain is the main grain-producing area. It has a mild climate, large areas of land, and abundant resources. From the ancient times to the present, this part of the country has been called the "land of fish and rice". It also has a high population density. 
The Qinghai - Tibet Plateau ${ }^{3}$ in South-Western region is the world's highest plateau. The Sichuan basin ${ }^{4}$ sits atop the Himalayas, in an area where the Himalayas are pushing east. In this region, geography is devious and traffic is inconvenient. However, from everlasting, the Sichuan basin is called "nature's storehouse". Due to its relative flatness and fertile soils, it is able to support a population of more than 100 million (Li et al., 2011).

\section{Regional differences and economic development after the economic reform}

In 1978, China began to transform its highly centralized planned economy into a market economy. Its regional economic development strategies were also changed as the Chinese government prioritized efficiency and proposed a hierarchical development strategy for China's regions. As a re-

${ }^{3}$ Qinghai - Tibet Plateau is a vast elevated plateau in Central Asia and East Asia, covering most of the Tibet Autonomous Region, Northwestern Yunnan, Western half of Sichuan, Southern Gansu and Qinghai provinces in Western China, Indian regions of Ladakh and Lahaul and Spiti (Himachal Pradesh) as well as Bhutan.

${ }^{4}$ Sichuan basin is a lowland region in southwestern China. The basin is anchored by Chengdu, capital of Sichuan province, in the west, and the direct-administered municipality of Chongqing in the east. sult, eastern coastal areas developed significantly faster than other areas.

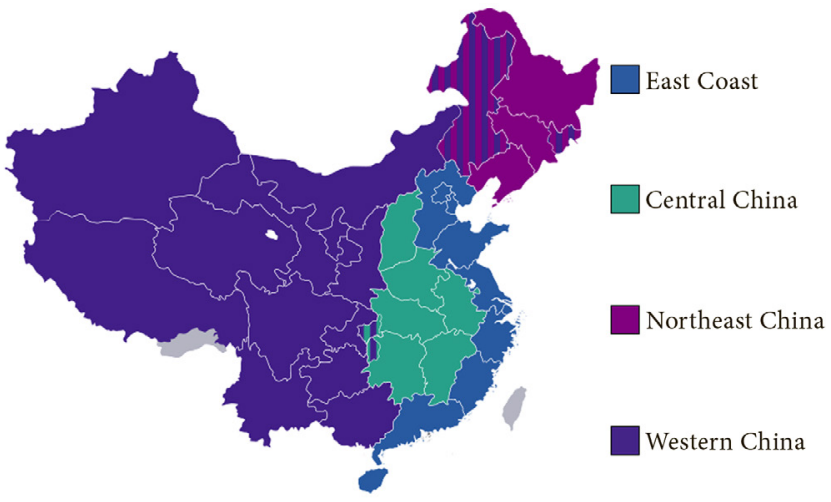

Figure 2. Economic regions in mainland China Source: p.51vv. https://p.51vv.com/vp/im8HdIZu (In Chinese)

At the end of the $20^{\text {th }}$ century, the government decided to establish special economic zones (SEZ) and open them to foreign investors. The southeast coast has been a trading port since ancient times and had a convenient transportation infrastructure. In addition, foreign capital has also been active in these areas, which made coastal areas suitable for establishing SEZs. In a short while, the number of production facilities and SMEs (medium-sized and small enterprises) increased.

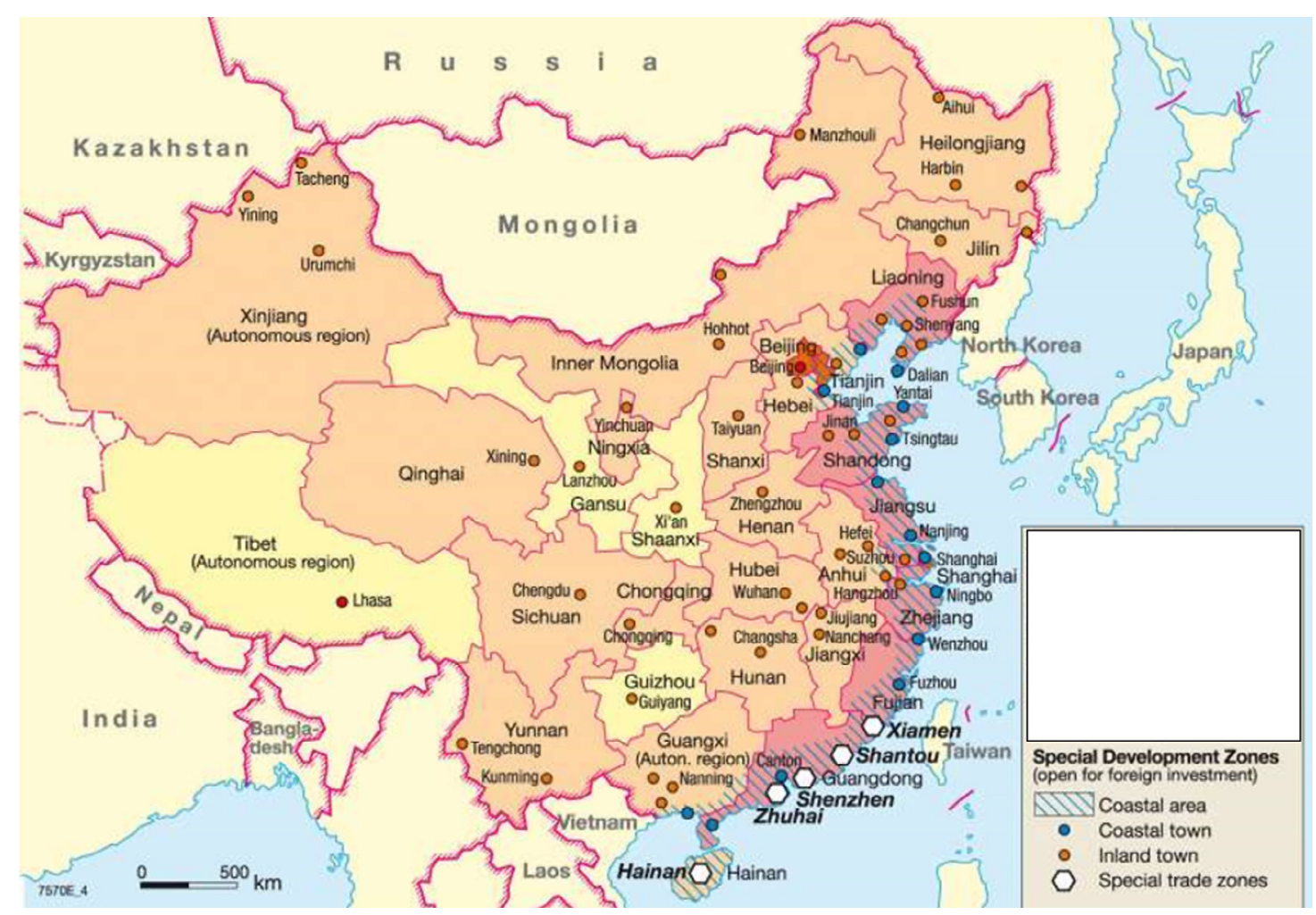

Figure 3. China's Special Economic Zones

Source: The geography of transport system. Retrieved from:

https://transportgeography.org/contents/chapter7/globalization-international-trade/china sez-2/ 
The economic development of the coastal areas gave the Chinese government confidence to continue the reforms. After the 1990s, they established an open area along the Yangtze River and an open area along the border. Some of these areas have close business relations with neighboring countries and the cities located along the Yangtze River serve as major transportation hubs.

At the same time, as open areas continued to expand, the government launched the strategy of opening to the outside world and some inland cities were included into the open zones. Foreign capital has also begun to enter the tertiary industry, warehousing, transportation, trade, and real estate sectors.

Figure 4 illustrates that after the economic reforms in mainland China, the economies of all regions showed tremendous growth. However, the regional disparities did not decrease and even tended to exacerbate, with the East Coast leaving other regions far behind.

Coastal areas' specialization on processing of imported materials contributed to China's export-oriented economy, maintaining the balance of trade. China has begun to develop economic and trade exchanges with countries around the world. To address the sluggish slow economic development in some regions, China proposed regional development strategies such as the Rise of Central China Plan, China Western Development, and Revitalization of the Old Northeast Industrial Bases in the early $21^{\text {st }}$ century.

China Western Development policy was adopted in 2000 for western regions, which account for $71.4 \%$ of mainland China, but only $28.8 \%$ of the population as of 2002. The strategy is mostly aimed at the development of infrastructure, attraction of foreign investment, environmental conservation (e.g. reforestation), promotion of education, and retention of talent from flowing to richer provinces.

China's attempt to develop its western regions has had varying effects on its economic development. Massive investment has boosted the region's output, it effectively raised GDP in all western regions. The per capita income increased as well as the immigration rate in many provinces. By and large, the project, however, failed to achieve its goal of eliminating the economic gap between China's East and West. In Western China, some top cities such as Chengdu, Chongqing, Xian, etc., emerged and reached high economic development levels. (Maimaitiming \& Cao, 2010).

Revitalization of the Old Northeast Industrial Bases was aimed to rejuvenate the industrial bases which once functioned as the center of heavy industry in China. It should be noted that Northeastern China is an old industrial area and is known as the "Eldest Son of the Republic". It had a developed transportation infrastructure and was a rich region. However, nowadays the infrastructure has become outdated and many large state-owned plants are struggling. The state-owned economy dominates and SMEs are weak while the economy in general lacks vitality. High urbanization rates make it difficult for this region to transform. The main industries that the revitalization policy was being targeted at are pe-

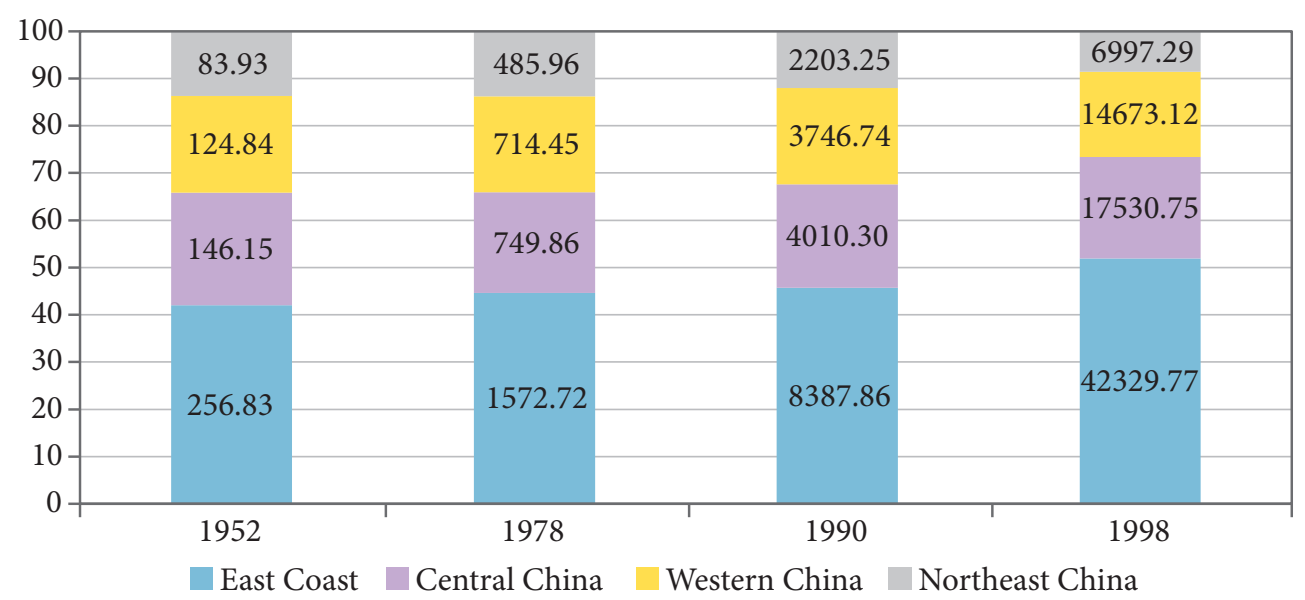

Figure 4. GDP by region in 1952-1998,100 million yuan*

Source: compiled based on the data of www.yearbookchina.com. East Coast, Central, Northeast and Western China Economic Development Index (In Chinese) Retrieved from: https://www.yearbookchina.com/navipage-n3019100819000183.html (Accessed: 02.10.2020).

* The term "Yuan" refers to the primary unit of account of the renminbi (RMB), the currency of the People's Republic of China. 
troleum, chemical, automobile, tourism, import and export trade, and light industrial manufacturing.

After 10 years of development, in 2013 and 2014, with the slowdown of the national economy, the disadvantage of the north-eastern industrial structure, with its orientation towards the supply of raw materials, became more obvious. In addition, many cities in the three provinces of Northeast China have demonstrated sluggish growth rates. Thus, it can be concluded that the first round of the revitalization policy in the north-eastern regions have actually been a failure (Ma \& Zhang, 2020).

The Rise of Central China Plan is a policy adopted to accelerate the development of central regions. The focus of development during this period is to promote industrialization and urbanization and increase investment in the construction of agricultural infrastructure. One of the targets is also to develop energy and raw material industrial bases. The plan was aimed at building a comprehensive transportation system and infrastructure (e.g. logistics centres) and at improving the market system.

In the way similar to China Western Development, this plan resulted in the appearance of a number of high performing cities and urban clusters, including the Wuhan city circle and Zhengzhou city group.

\section{Urbanization and city clusters in mainland China}

As Figure 5 illustrates, although Northeastern China has been implementing the policy for revitalization of the old industrial centres for 20 years, compared with other regions, its development is still not satisfactory. This has also led to a large brain drain from this region. Meanwhile, although the proportion of GDP in the East Coast declined only slightly, it has always remained above $50 \%$, and the development is very rapid. In recent years, there have appeared a number of high performing cities and city clusters in western and central regions.

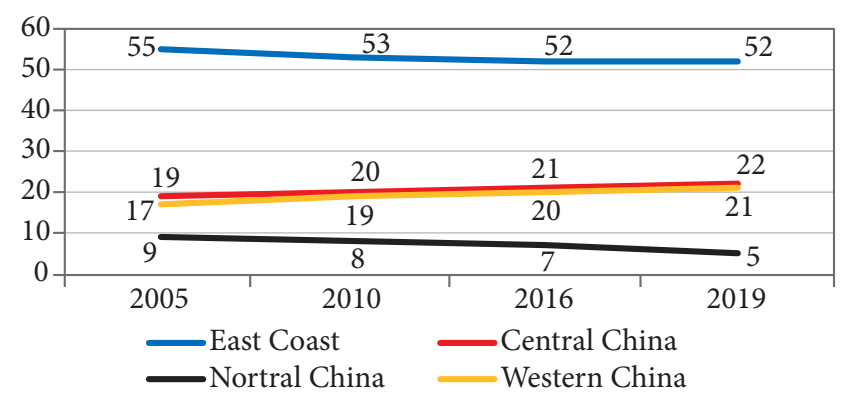

Figure 5. Regions' share in GDP in 2005-2019, \% Source: based on the data of www.yearbookchina.com. East Coast, Central, Northeast and Western China Economic Development Index (In Chinese). Retrieved from: https://www.yearbookchina.com/ navipage-n3019100819000183.html

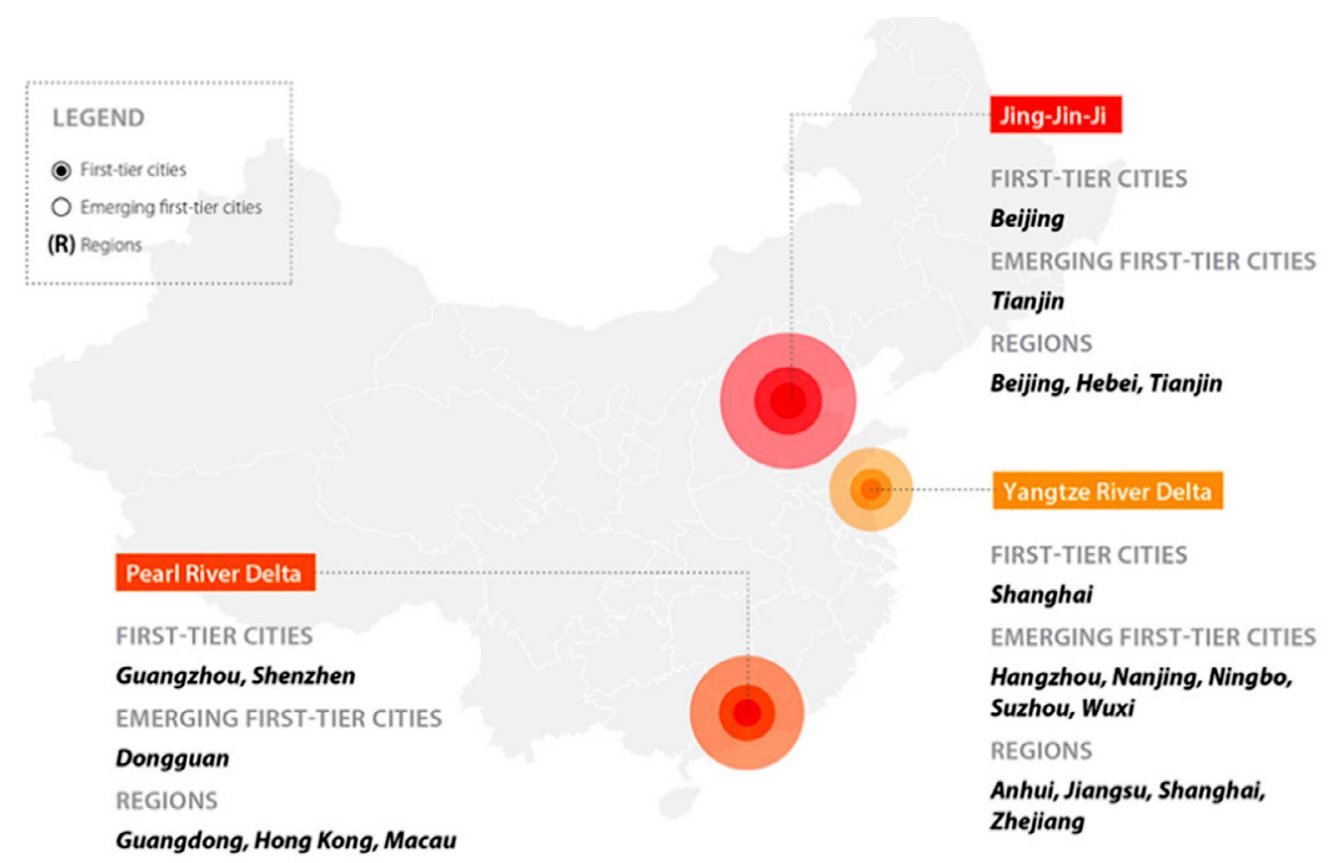

Figure 6. China's city clusters: Jing-Jin-Ji, Yangzte River Delta, Pearl River Delta

Source: China Briefing. Retrieved from https://www.china-briefing.com/news/chinas-mega-city-clusters-jing-jin-ji-yangzteriver-delta-pearl-river-delta/?hilite=\%27China\%E2\%80\%99s\%27\%2C\%27mega $\% 27 \% 2 \mathrm{C} \% 27$ city $\% 27 \% 2 \mathrm{C} \% 27$ clusters $\% 27$ 
China's imports and exports suffered significantly due to the COVID-19 pandemic in 2020. Moreover, there was an economic downturn in some of the city clusters, which makes it difficult for us to estimate the full scale of these clusters' contribution to the national economy. Therefore, in our estimations we are going to use the data for 2019.

There are three super-regions in China - JingJin-Ji, the Yangzte River Delta (YRD), and Pearl River Delta (PRD) - that can compete against other such regions around the world, including Tokyo Bay, New York Tri-State Area, and San Francisco Bay Area (see Fig. 6).

Calculated according to the exchange rate in 2019 , total GDP of Jing-Jin-Ji is about 1,29 trillion dollars, which means that this region surpassed Mexico, Indonesia, and Turkey. It ranks among the top 20 global GDPs, with per capita GDP of 11,500 dollars, exceeding the global per capita GDP level (11,300 dollars). In Jing-Jin-Ji, Beijing takes advantage of being the center of government, with the city being the strongest research base in China. In a word, Beijing has more unicorn startup companies than any other Chinese city.

According to Table 1 above, the YRD accounts for nearly a quarter of China's total GDP: with less than $4 \%$ land area, it is one of the most important drivers of China's economy. The YRD also has the largest number of economically competitive cities such as Shanghai (an international hub and regional headquarters of many multinationals), Suzhou (top destination for technology manufacturing), Nanjing (important R\&D centre), and Hangzhou (home to Chinese giants, e.g. Alibaba and Geely).

Being placed at the center of China's "reform and opening-up" policy, the PRD has generally been regarded as the country's most open region. In the PRD, Shenzhen has a dynamic entrepreneurship and start-up environment. It has more patent applications than any other Chinese city and it is home to such innovative companies as BYD, Tencent, and Huawei (Pan \& Yang, 2019).

China's world-class city clusters have their own unique relative strengths: for example, the YRD is the most economically significant cluster and it has the most developed infrastructure, the PRD, boasting Hong Kong, is the most open, while Jing-Jin-Ji has the innovative strength of Beijing. (Wu, 2016).

In addition to the three city clusters described above, there is also the rapidly developing the
Yangtze River Economic Belt in mainland China. It is composed of the Yangtze River Delta, Yangtze River Middle Reaches clusters and the Chengdu-Chongqing cluster. With Jing-Jin-Ji and the PRD, they form the most important locomotive of China's economy (Cheng et al. 2017).

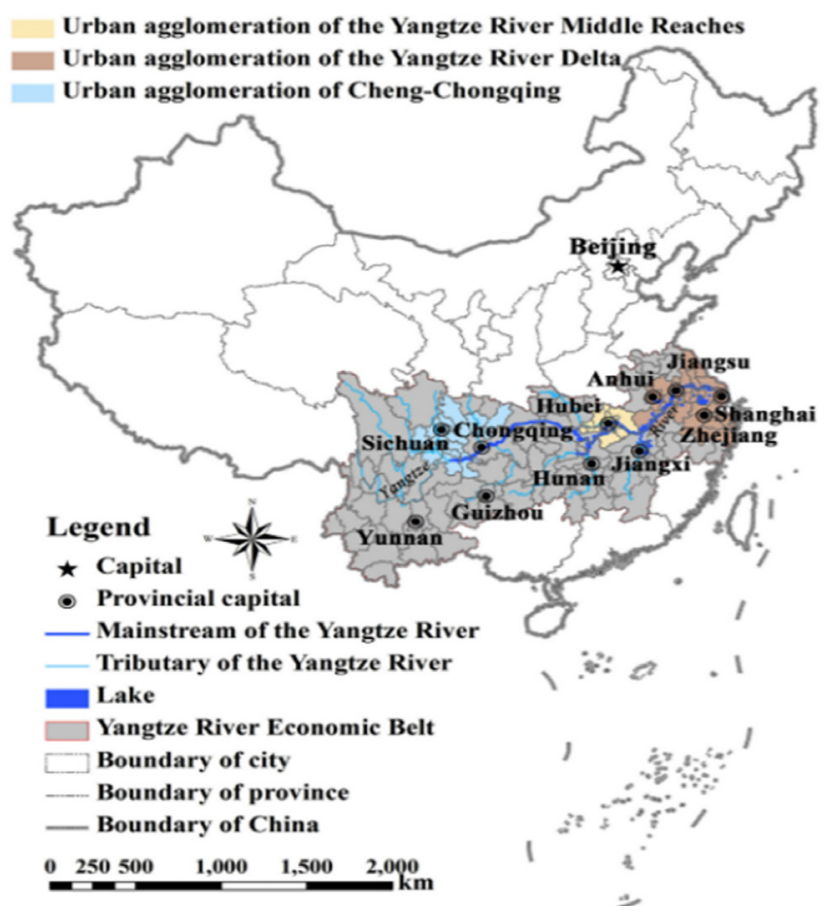

Figure 7. Yangtze River Economic Belt of China

Source: The trade-offs and determinants of ecosystem services in China's Yangtze River. Economic Belt in 2000-2015

(Xu et al., 2018)

In mainland China, there are 19 city clusters that have been built or are under planning, and the above five are the most promising. According to Tables 1 and 2, these city clusters cover $24.22 \%$ of China's total land area and support 780 million people, $55.6 \%$ of the country's total population. They also contribute $63.87 \%$ to the country's GDP.

These cities differ significantly from other small or immature city clusters. These differences, coupled with regional disparities, create China's hierarchy of cities.

The Chinese city tier system is a hierarchical classification of Chinese cities. The Chinese government, however, didn't publish or recognize any official definition of the city tier system. However, the tier system has gained wide popularity in recent years as a point of reference. The tiers reflect the differences in consumer behavior, income level, population size, consumer sophistication, infrastructure, talent pool, and business opportunity.

In 2019, Yicai Global, a financial magazine, published a tiered list of the most commercially 
attractive cities in China (see Table 3 above). The list comprises 337 cities, divided into 6 levels: tier 1 , new tier 1 , tier 2 , tier 3 , tier 4 , and tier 5 . For the sake of brevity, this article only lists the top 2 tiers. For the consumer market, these cities are also called "high-tier cities".
In the 19 first-tier and new-tier 1 cities, less than $3 \%$ of the land is occupied by nearly $18 \%$ of China's population, but these cities account for 33\% of GDP and nearly $60 \%$ of imports and exports (see Table 4). They also account for nearly a quarter of the country's public revenue (Deng et al., 2020).

Statistics on the main economic indicators in Jing-Jin-Ji, the YRD, and PRD in 2019

\begin{tabular}{|c|c|c|c|c|c|}
\hline & $\begin{array}{c}\text { Permanent Population } \\
\text { at the Year-end } \\
\text { (10 000 people) }\end{array}$ & $\begin{array}{c}\text { Land Area } \\
(10000 \text { sp.km) }\end{array}$ & $\begin{array}{c}\text { GDP } \\
\begin{array}{c}(100 \text { million } \\
\text { yuan })\end{array}\end{array}$ & \begin{tabular}{|c|} 
Total Exports \\
and Imports \\
$(100$ million yuan $)$
\end{tabular} & Cities \\
\hline Jing-Jin-Ji & 11307.4 & 21.6 & 84580.1 & 23655.6 & 14 \\
\hline As Percentage of National Total (\%) & $8.1 \%$ & $2.25 \%$ & $8.6 \%$ & $7.5 \%$ & - \\
\hline Yangtze River Delta & 22714.0 & 35.1 & 237252.6 & 114930.1 & 26 \\
\hline As Percentage of National Total (\%) & $16.2 \%$ & $3.66 \%$ & $24.1 \%$ & $36.4 \%$ & - \\
\hline Pearl River Delta & 6446.9 & 5.5 & 86899.05 & 68281.91 & 9 \\
\hline As Percentage of National Total (\%) & $4.6 \%$ & $0.57 \%$ & $8.77 \%$ & $21.6 \%$ & - \\
\hline
\end{tabular}

Source: based on the data of www.yearbookchina.com. Statistics of the Main Economic Indicators of Jing-Jin-Ji, Yangtze River Economic Belt and Yangtze River Delta (In Chinese). Retrieved from: https://www.yearbookchina.com/navipage-n3020013013000111. html (Accessed: 07.10.2020). Main Economic Indicators of the Pearl River Delta (In Chinese). Retrieved from: https://www.yearbookchina.com/navipage-n3019100803000581.html (Accessed: 07.10.2020).

Statistics on the main economic indicators in the Yangtze River Economic Belt in 2019

\begin{tabular}{|c|c|c|c|c|c|}
\hline $\begin{array}{l}\text { Yangtze River } \\
\text { Economic Belt }\end{array}$ & $\begin{array}{c}\text { Permanent Population } \\
\text { at the Year-end } \\
(10000 \text { people })\end{array}$ & $\begin{array}{c}\text { Land Area } \\
(10000 \text { sp.km })\end{array}$ & $\begin{array}{c}\text { GDP } \\
(100 \text { million yuan })\end{array}$ & $\begin{array}{c}\text { Total Exports } \\
\text { and Imports } \\
\text { (100 million yuan) }\end{array}$ & Cities \\
\hline Data & 60205.8 & 205.23 & 457805.2 & 139828.7 & 42 \\
\hline As Percentage of National & $42.9 \%$ & $21.4 \%$ & $46.5 \%$ & $44.3 \%$ & - \\
\hline
\end{tabular}

Source: based on the data of www.yearbookchina.com. Statistics of Main Economic Indicators of Jing-Jin-Ji, Yangtze River Economic Belt and Yangtze River Delta (In Chinese). Retrieved from: https://www.yearbookchina.com/navipage-n3020013013000111. html (Accessed: 07.10.2020).

Table 3

Top 2 Tiers of Chinese Cities \& Ranking of Cities' Business Attractiveness

\begin{tabular}{|l|l|c|}
\hline \multicolumn{1}{|c|}{ Tier } & \multicolumn{1}{|c|}{ Cities } & Number of cities \\
\hline Tier 1 & Beijing, Shanghai, Guangzhou, Shenzhen & 4 \\
\hline New Tier 1 & $\begin{array}{l}\text { Chengdu, Hangzhou, Chongqing, Wuhan, Xian, Suzhou, Tianjin, Nanjing, Changsha, } \\
\text { Zhengzhou, Dongguan, Qingdao, Shenyang, Ningbo, Kunming }\end{array}$ & 30 \\
\hline Tier 2 & $\begin{array}{l}\text { Wuxi, Foshan, Hefei, Dalian, Fuzhou, Xiamen, Harbin, Jinan, Nanning, Changchun, } \\
\text { Quanzhou, Shijiazhuang, Guiyang, Nanchang, Jinhua, Changzhou, Nantong, Jiaxing, } \\
\text { Taiyuan, Xuzhou, Huizhou, Zhuhai, Zhongshan, Taizhou, Yantai, Lanzhou, Shaoxing, } \\
\text { Haikou, Yangzhou }\end{array}$ & \\
\hline
\end{tabular}

Source: based on the data of Yicai Global. 2019 tiers of cities. Retrieved from: https://www.yicai.com/news/100200192.html (In Chinese, accessed: 12.10.2020).

Statistics on main economic indicators in tier 1 and new tier 1 cities in 2019

\begin{tabular}{|l|c|c|c|c|c|l|}
\hline $\begin{array}{c}\text { As Percentage } \\
\text { of National Total }\end{array}$ & $\begin{array}{c}\text { Permanent Population } \\
\text { at the Year-end }\end{array}$ & $\begin{array}{c}\text { Land } \\
\text { Area }\end{array}$ & GDP & $\begin{array}{c}\text { Total Exports } \\
\text { and Imports }\end{array}$ & $\begin{array}{c}\text { Public } \\
\text { finance-revenue }\end{array}$ & \multicolumn{1}{|c|}{ Economic regions } \\
\hline Tier 1 & $5 \%$ & $0.34 \%$ & $13 \%$ & $32.5 \%$ & $10 \%$ & 17 cities in the \\
\hline New Tier 1 & $12.5 \%$ & $2.33 \%$ & $20 \%$ & $26.1 \%$ & $12 \%$ & East Coast or 5 city clusters \\
\hline
\end{tabular}

Source: based on the data of www.yearbookchina.com. Statistics of the Main Economic Indicators of these cities. (In Chinese) Retrieved from: https://www.yearbookchina.com (Accessed: 14.10.2020). 


\section{Problems caused by regional economic disparities}

The latest Gini coefficient shows that mainland China has reached the level of 0.465 , which is a rather alarming figure, meaning that the gap between the rich and the poor is too wide and the income distribution is uneven. Such income gap mainly stems from the difference between the coast and the inland, and between urban and rural areas.

In this respect, it will be illustrative to compare several large cities belonging to different tiers of the hierarchy (Table 5; Figure 8). The Tier 1 cities have reached the level of developed countries, and the migrant population in these cities also accounts for a considerable proportion of the to- tal population. These cities are densely populated (Hu \& Wang, 2019).

The development level of coastal cities in New Tier 1 or Tier 2 cities is much higher than that of other cities of the same level. Therefore, the Chinese city tier system does not fully conform to reality. Eastern coastal cities are still far ahead of their counterparts in other regions.

No matter whether the cities in Northeastern China high-tier cities are, the brain drain is very serious. Residents' disposable income and consumption expenditures are relatively low compared to other regions. In recent years, the development of northeastern cities has been rather sluggish, except for agriculture and heavy industry, which causes an outflow of migrants to other regions.

Index of development of cities from different tiers (2018-2019)

\begin{tabular}{|c|c|c|c|c|c|c|c|c|}
\hline Cities & $\begin{array}{l}\text { Economic } \\
\text { regions }\end{array}$ & $\begin{array}{l}\text { Mature city } \\
\text { clusters }\end{array}$ & $\begin{array}{c}\text { Per } \\
\text { Capita } \\
\text { GDP } \\
\text { (Yuan) }\end{array}$ & $\begin{array}{l}\text { Deposits in } \\
\text { Renminbi and } \\
\text { Foreign Cur- } \\
\text { rencies in All } \\
\text { Financial } \\
\text { Institutions } \\
(100 \text { million } \\
\text { yuan })^{\star}\end{array}$ & $\begin{array}{c}\text { Human } \\
\text { Devel- } \\
\text { opment } \\
\text { Index }^{*}\end{array}$ & $\begin{array}{c}\text { Percentage } \\
\text { of perma- } \\
\text { nent mi- } \\
\text { grant pop- } \\
\text { ulation to } \\
\text { permanent } \\
\text { population* }\end{array}$ & $\begin{array}{l}\text { Popu- } \\
\text { lation } \\
\text { density } \\
\text { (per } \\
\text { sq.km) }\end{array}$ & $\begin{array}{c}\text { Annual } \\
\text { average } \\
\text { concen- } \\
\text { tration of } \\
\text { PM2.5 } \\
\left(\mu \mathrm{g} / \mathrm{m}^{3}\right)\end{array}$ \\
\hline Beijing (Tier 1) & East Coast & Jing-Jin-Ji & 164000 & 171062.3 & very high & $34.60 \%$ & 1312 & 42 \\
\hline Shenzhen (Tier 1) & East Coast & PRD & 203489 & 83942.45 & very high & $63,20 \%$ & 6730 & 24 \\
\hline $\begin{array}{l}\text { Chengdu (New } \\
\text { Tier 1) }\end{array}$ & Western China & $\begin{array}{c}\text { Yangtze River } \\
\text { Economic Belt }\end{array}$ & 103386 & 39828 & high & $9.53 \%$ & 1157 & 43 \\
\hline $\begin{array}{l}\text { Kunming } \\
\text { (NewTier 1) }\end{array}$ & Western China & $\begin{array}{c}\text { Yangtze River } \\
\text { Economic Belt }\end{array}$ & 93853 & 14909.26 & high & $16.77 \%$ & 294.76 & 26 \\
\hline Wuxi (Tier 2) & East Coast & $\begin{array}{l}\text { Yangtze River } \\
\text { Delta }\end{array}$ & 180000 & 17605.46 & very high & $23.72 \%$ & 1420 & 39 \\
\hline Lanzhou (Tier 2) & Western China & - & 75217 & 8875.5 & - & $12.44 \%$ & 315 & 36 \\
\hline Baoding (Tier 3) & Central China & Jing-Jin-Ji & 34374 & 7241 & - & $-15 \%$ & 1109 & 50,2 \\
\hline Jilin (Tier 3) & $\begin{array}{l}\text { Northeastern } \\
\text { China }\end{array}$ & - & 34335 & 2904,3 & - & $-20 \%$ & 140 & 38 \\
\hline Xining (Tier 4) & Western China & - & 41429 & 4020,89 & - & $12.29 \%$ & 311 & 39 \\
\hline $\begin{array}{l}\text { Xishuangbanna } \\
\text { (Tier 4) }\end{array}$ & Western China & $\begin{array}{c}\text { Yangtze River } \\
\text { Economic Belt }\end{array}$ & 47659 & 688.69 & - & $15 \%$ & 63 & 18 \\
\hline $\begin{array}{l}\text { Fangchenggang } \\
\text { (Tier 5) }\end{array}$ & Western China & $\begin{array}{l}\text { Near Guang } \\
\text { dong }\end{array}$ & 73163 & 779.23 & - & $-4.20 \%$ & 1.91 & 29 \\
\hline Pu'er (Tier 5) & Western China & $\begin{array}{c}\text { Yangtze River } \\
\text { Economic Belt }\end{array}$ & 33098 & 928.04 & - & $3 \%$ & 58.39 & 9 \\
\hline
\end{tabular}

Source: based on the data of www.yearbookchina.com, National Bureau of Statistics of China. Retrieved from: http://www. stats.gov.cn/tigz/tjdt/202005/t20200522 1747505.html (Accessed: 20.10.2020).

* Deposits in Renminbi and Foreign Currencies in All Financial Institutions represent the total capital of a city, which shows how much capital the city can gather, the overall strength of the city, and the city's innovation potential.

* The Human Development Index is used to rank countries into four tiers. Only countries in the first group of "very high" development can be considered developed.

* Percentage of the permanent migrant population to permanent population shows the flow of population in a city. The larger the number, the more popular is the city among residents of other cities. Cities with negative scores suffer from serious population losses.

* The annual average concentration of PM2.5 shows the air quality index of a city. The higher is the index, the worse is the air quality (Ma et al., 2016). 


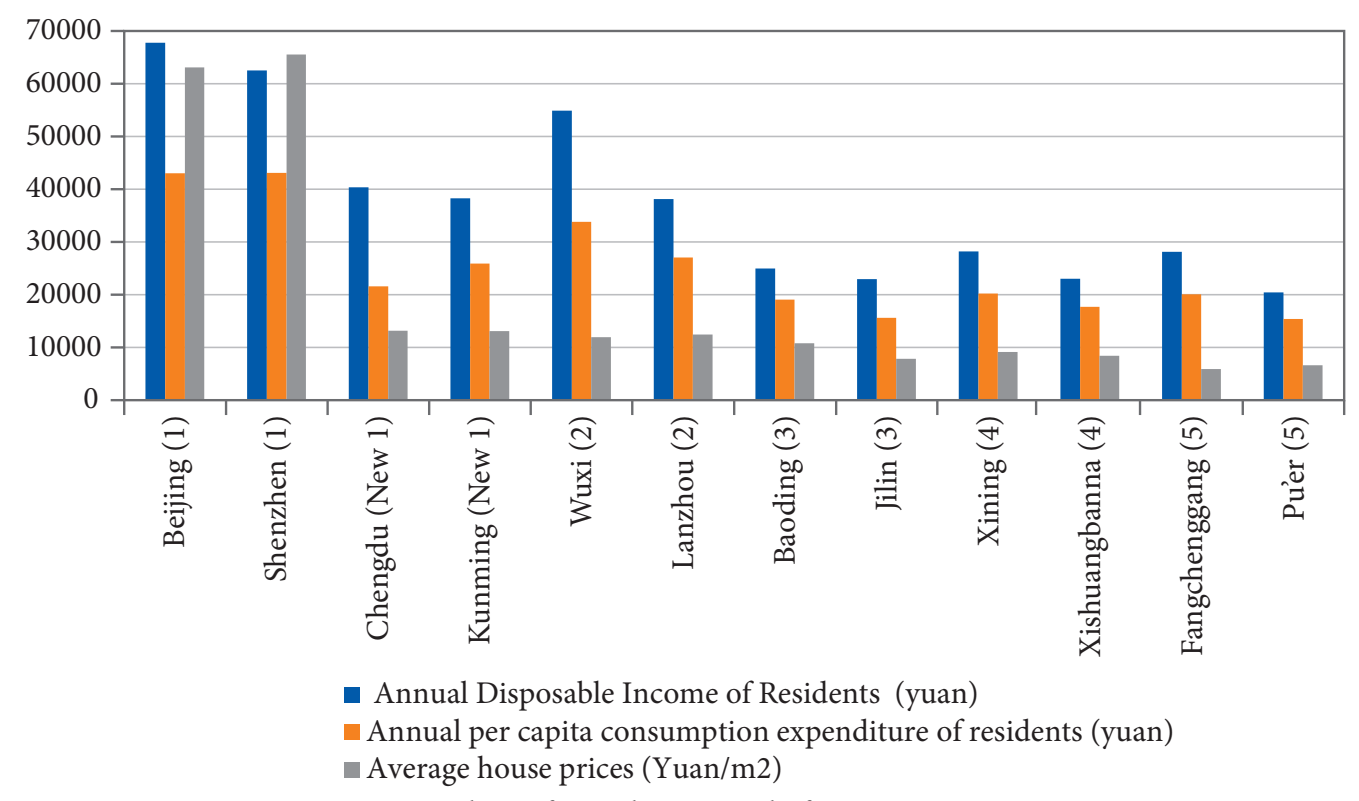

Figure 8. Living index of residents in different cities in 2019, yuan

Source: compiled based on the data of www.yearbookchina.com, National Bureau of Statistics of China. Retrieved from http://www.stats.gov.cn/tigz/tidt/202005/t20200522 1747505.html.

Real estate rental and sale service platform "Anjuke". Retrieved from https://www.anjuke.com/ (Accessed: 20.10.2020).

Small cities located near mega-cities (e.g. Baoding next to Beijing and Fangchenggang near Guangdong) megacities often suffer more population losses. The air quality in the southwest is good, the population density is lower, the immigration is increasing year by year, and the housing prices are low. However, the infrastructure, education, and medical standards of these cities are rather low. (Li et al., 2019)

The huge regional differences in mainland China have led to regional discrimination, which sometimes even resembles nationality discrimination. For residents of Beijing and Shanghai, their household registration means that they enjoy a better living environment and occupy a higher position in the social hierarchy. Residents of low-tier cities migrate to high-tier cities, which increases population density and puts more pressure on the public resources, leading to the so-called "big city disease". Traffic congestion and environmental degradation in these cities have become a norm, and the cost of living and consumption expenditures are also increasing. (Xu et al., 2019) The loss of population, especially young adults, and resources in smaller cities has also become rather typical, leading to lower rates of infrastructure construction, substandard medical and education services.

The Chinese government has established a special household registration system to prevent and control population migration. This system is directly linked to welfare benefits, school attendance, and employment opportunities. Children's household registration is affected by their parents' household registration. Thus, it is easier for children in big cities to get into good universities. People with local registration can apply for commodity housing, otherwise, they can only buy commercial housing, which requires more expenses. However, while such system controls immigration, it imposes restrictions on people's mobility depending on their origin and thus widens the gap between the rich and poor, exacerbating social differentiation. People with household registration in big cities are in a superior position to inhabitants of smaller cities or rural areas. (Wang \& Tong, 2016)

\section{Transformation and future adjustments}

In response to possible crises in regional development, the Chinese government put forward an adjustment plan in August 20195. At the Fifth Meeting of the Central Committee for Financial and Economic Affairs, it was proposed that the new regional economic plan should be realized by improving space management and adapting to the core functions and local conditions of each region.

${ }^{5}$ News Portal of The State Council of the People's Republic of China. http://english.www.gov.cn/news/topnews/201908/26/ content WS5d63elf3c6d0c6695ff7f51e.html. 
In general, what the plan comes down to is that each city should have its own role. The key provisions of the plan are as follows:

1. The concentration of resources in central cities and city clusters is a trend, and these cities need to increase their capacity, not just control the number of residents. The household registration system will gradually become looser, and the city residence restrictions will be lifted in 2022 . This will enhance the mobility of labor and talent. Large cities will expect to acquire more construction land and thus will be able to accommodate more people.

2. China will expand free trade zones (FTZ) to six new provinces across the country - Jiangsu, Shandong, Hebei, Heilongjiang, Guangxi, and Yunnan. The aim is to deepen China's trade and economic ties with the neighboring countries, while also bolstering the local economy in lagging provinces.

FTZs will be created in the following provinces:

- Yunnan, the landlocked province that borders Vietnam, Laos, and Myanmar;
- Guangxi, the southern autonomous region that borders Vietnam;

- Heilongjiang, the northeastern province that borders Russia;

- Shandong, Jiangsu, and Hebei, the coastal provinces that sit across the ocean from South Korea and Japan.

3. Tier 1 and New Tier 1 cities in the coastal areas will adjust their industrial structure and develop new materials, e-commerce, digital economy, etc. Other high-tier cities and low-tier cities need to determine their own advantageous products. The industry should be centralized and specialized, cross-border e-commerce should be developed. Infrastructure should also be improved to equalize public services. The purpose is to make small cities truly economically attractive, capitalizing on their inherent environmental advantages, and thus let residents live voluntarily in small and medium cities. (Jiang, Li \& Fu, 2021).

4. From the perspective of city clusters, the YRD is specializing on electronics, automobiles, finance, and other industries. The YRD is an international metropolis, similar to Shanghai, and

\section{China's 18 Pilot Free Trade Zones}

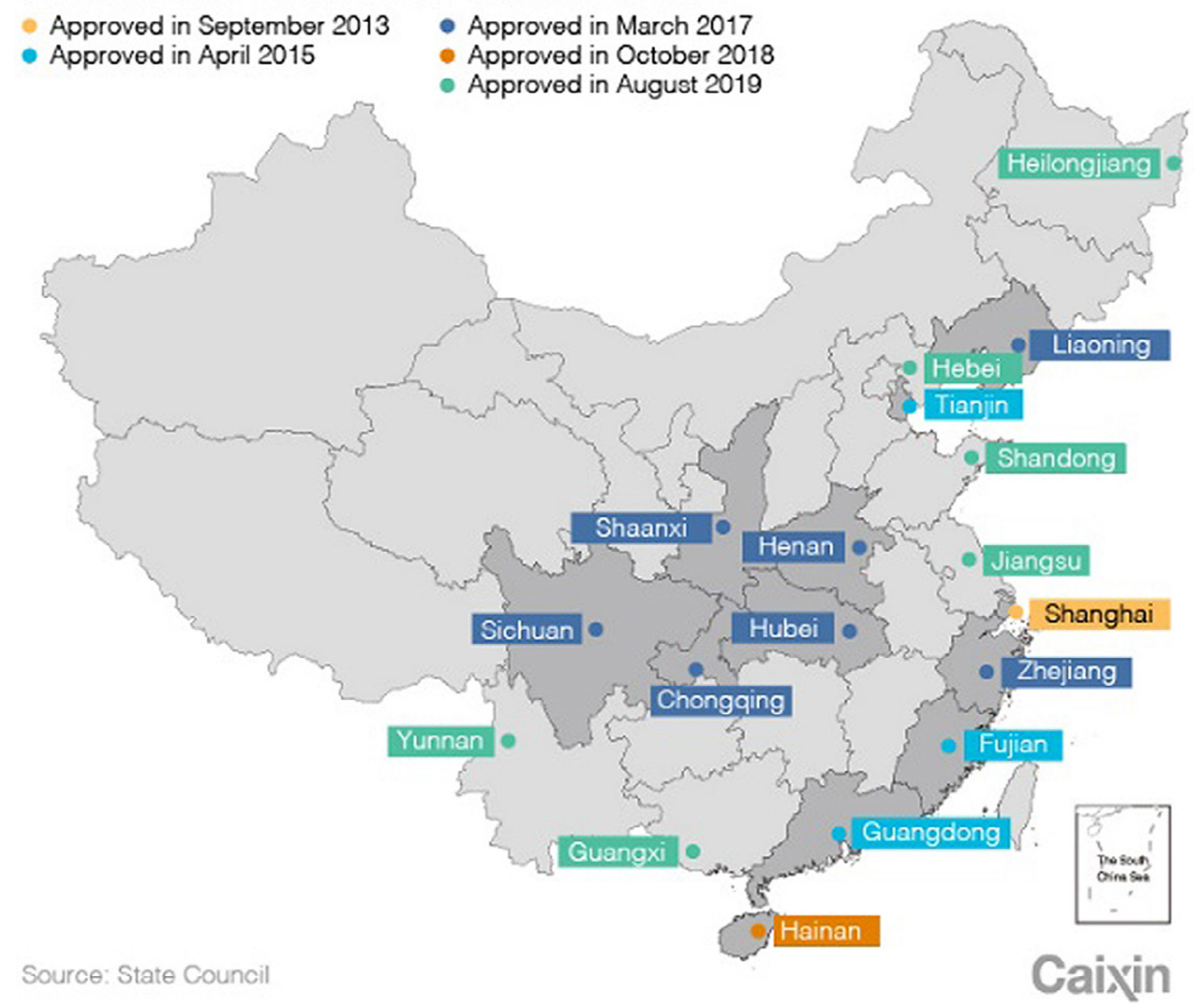

Figure 9. China's 18 pilot Free Trade Zones

Source: CX Daily: Central Bank Sets Deadlines for Adopting New Lending Rates. Retrieved from https://www.caixinglobal. com/2019-09-03/editorial-chinas-free-trade-zones-must-adapt-to-local-conditions-101458277.html 
is, therefore, very attractive for migrants from other Chinese cities. The PRD is closely linked with Hong Kong and Macao. China will build the Guangdong-Hong Kong-Macao Greater Bay Area and turn it into a base for world emerging industries, advanced manufacturing, and modern service industries. Jing-Jin-Ji will reduce high-energy-consuming industries and focus on "high-end manufacturing + technological innovation" in the future. In addition, Jing-Jin-Ji plans to build a city sub-center, so that Beijing will not be a monopoly, and other cities will become stronger. In the future, the Yangtze River Economic Belt will promote new industrialization, informatization, and agricultural modernization, it will create a worldclass advanced manufacturing belt, and enhance regional core competitiveness. (Wang et al., 2020)

5. As for the lagging regions, such as those in north-western China, they might benefit from "The Belt and Road Initiative" to popularize more infrastructure and invest overseas. North-eastern China will adjust the economic structure, advance the diversified development of industries, accelerate the reform of state-owned enterprises, create a free trade pilot zone, and accelerate the transformation of government functions. At the same time, the developing multilateral trade with Russia and other countries is important. Effective transfer payments should be established in less developed regions. The government is planning to grant resident pensions, unemployment subsidies, relief funds, agricultural product price subsidies, social insurance benefits, etc. The purpose of these plans is to reduce the difference in living standards between less and more developed regions. (Zhang \& Cheng, 2007)

\section{Conclusion}

In this paper, we looked at the regional differences in mainland China, their causes, resulting problems and possible solutions. We also weighed the pros and cons of the geographical conditions and resources in various regions of mainland China and discussed their respective economic potentials. We also considered the economic reform of the 1970s and its results. The social implications of the regional disparities in China were also outlined as well as the new economic plans and adjustments were analyzed.

All of the above has led us to the following conclusions. One of the reasons behind regional disparities in China is the geographical barriers. After the implementation of the economic reforms in 1978, four economic regions (East Coast, Central China, Northeast China, Western China) were formed in China. Yet another outcome of the reform was the appearance of city clusters and a city tier system. The huge imbalance in the economic development exacerbated social differentiation, brought about regional discrimination, overpopulation of big cities and the outflow of working-age population from small cities. To tackle these problems, the Chinese government formulated adjustment plans so that each region could play its own role in the economic development.

From the perspective of regional differences theory, the contribution of this study is that it can prove useful for investors and business activists in mainland China in gaining a better understanding of the differences between various regions and helping them develop new investment and partnership ideas.

\section{References}

1. Candelaria, C., Daly, M., \& Hale, G. (2015). Persistence of regional wage differences in China. Pacific Economic Review, 20, 365-387. doi: 10.1111/1468-0106.12113.

2. Cheng, Y., Liu, W., \& Lu, J. (2017). Financing innovation in the Yangtze River Economic Belt: rationale and impact on firm growth and foreign trade. Canadian Public Policy-Analyse De Politiques, 43, S122-S135. doi: 10.3138/cpp.2016-077.

3. Deng, Z., Qin, M., \& Song, S. (2020). E-study on Chinese city size and policy formation. China Economic Review. 60, 101390. doi: 10.1016/j.chieco.2019.101390.

4. Hu, W., \& Wang, R. (2019). Which Chinese cities are more inclusive and why? Cities, 86, 51-61. doi: 10.1016/j.cities.2018.12.010.

5. Kasimu, A., Ghulam, A., \& Tateishi, R. (2009). Quantifying urban land cover dynamics and its environmental impacts in china using GLCNMO urban and satellite imagery. In Gidudu, A., Abe, B. T. \& Marwala, T. Investigating the effect of ensemble size on classification accuracy. Paper presented at the Proceedings of the International Conference on Earth Observation for Global Changes (EOGC2009), Chengdu, Sichuan (pp. 2200-2206). Chengdu: Chengdu University of Technology. 
6. Jiang, X., Li, G.L., \& Fu, W. (2021). Government environmental governance, structural adjustment and air quality: A quasi-natural experiment based on the three-year action plan to win the blue sky defense war. Journal of Environmental Management, 277, 111470. doi: 10.1016/j. jenvman.2020.111470.

7. Li, Y.S., Li, A.H., Wang, Z.F., \& Wu, Q. (2019). Analysis on housing affordability of urban residents in Mainland China based on multiple indexes: taking 35 cities as examples. Annals of Data Science, 6(2), 305-319. doi: 10.1007/s40745-018-0168-x.

8. Li, Y., \& Taube, M. (2019). Introduction: The belt \& road initiative-manifestations, driving forces, and international responses. How China's Silk Road Initiative is Changing the Global Economic Landscape. pp. 1-18. doi: 10.4324/9780429455193-1.

9. Li, Z.Q., Ying, D.L., Li, H.K., Yang, G., Zeng, Q., Guo, X.Y., \& Chen, X. (2011). Evolution of the western Sichuan basin and its superimposed characteristics, China. Acta Petrologica Sinica, 27(8), 2362-2370. (In Chin.) doi: 1000-0569/2011/027( 08 )-2362-70.

10. Lin, W.Q., Wu, M.H., Zhang, Y., Zeng, R.J., Zheng, X.J., Shao, L., Zhao, L.Y., Li, S.X., \& Tang, Y. (2018). Regional differences of urbanization in China and its driving factors. Science China Earth Sciences, 61, 778-791. doi: 10.1007/s11430-016-9163-3.

11. Lin, Y.F., \& Liu, P.L. (2008). Economic development strategies and regional income gap in China. In Wan, G.H. (Eds.), Inequality and Growth in Modern China (pp. 56-78). China, Oxford University Press. doi: 10.1093/acprof:oso/9780199535194.003.0004.

12. Liang, C., \& Guo, Z.J. (2017). Environmental efficiency analysis of China's regional industry: a data envelopment analysis (DEA) based approach. Journal of Cleaner Production. 142, 846-853. doi: 10.1016/j.jclepro.2016.01.045.

13. Maimaitiming, A., \& Cao, H. (2010, 24 August - 26 August). Urban transition in Western China. In Piscataway, N.J. 2010 International Conference on Management and Service Science: MASS 2010. Paper presented at the 2010 International Conference on Management and Service Science (Wuhan, China), (pp. 1-4). doi: 10.1109/ICMSS.2010.5576491.

14. Ma, Y.R., Ji, Q., \& Fan, Y. (2016). Spatial linkage analysis of the impact of regional economic activities on PM2.5 pollution in China. Journal of Cleaner Production. 139, 1157-1167. doi: 10.1016/j. jclepro.2016.08.152.

15. Ma, Z., Li, C., \& Zhang, J. (2020). Understanding urban shrinkage from a regional perspective: case study of Northeast China. Journal of Urban Planning and Development, 146(4), 05020025. doi: 10.1061/(ASCE)UP.1943-5444.0000621.

16. Pan, F., \& Yang, B. (2019). Financial development and the geographies of startup cities: Evidence from China. Small Business Economics, 52(3), 743-758. doi: 10.1007/s11187-017-9983-2.

17. Qi, Y.Y. (2015). A study on differences of china's regional economic development level based on cluster analysis. MATEC Web of Conferences, 22, 05022. doi: 10.1051/matecconf/20152205022.

18. Wang, Y., \& Tong, Z.H. (2016). China's household registration system and its reform status. Journal of China Agricultural University Social Sciences, 1, 100-108. (In Chin.) doi: 10.13240/j.cnki. caujsse.20160226.001.

19. Wang, L., Xue, Y.B., Chang, M., \& Xie, Ch. (2020). Macroeconomic determinants of hightech migration in China: The case of Yangtze River Delta urban agglomeration. Cities, 107, 102888. doi: $10.1016 /$ j.cities.2020.102888.

20. Wu, F. (2016). China’s emergent city-region governance: a new form of state spatial selectivity through state-orchestrated rescaling. International Journal of Urban And Regional Research, 40(6), 1134-1151. doi: $10.1111 / 1468-2427.12437$.

21. Xiao, Z.L., Du, X.Y., \& Wu, C.Q. (2017). Regional difference and evolution and convergence of innovation capability in China: research on space and factorial levels. Sustainability, 9, 16-44. doi: $\underline{10.3390 / \text { su9091644. }}$

22. Xu, X., Yang, G.S., Tan, Y., Liu, J.P., \& Hu, H.Z. (2018). Ecosystem services trade-offs and determinants in China's Yangtze River Economic Belt from 2000 to 2015. Science of The Total Environment, 634, 1601-1614. doi: 10.1016/j.scitotenv.2018.04.046.

23. Xu, S.C., Miao, Y.M., Gao, C., Long, R.Y., Chen, H., Zhao, B., \& Wang, S.X. (2019). Regional differences in impacts of economic growth and urbanization on air pollutants in China 
based on provincial panel estimation. Journal of Cleaner Production, 208, 340-352. doi: 10.1016/j. jclepro.2018.10.114.

24. Zang, B., Lv, P., \& Warren, C.M.J. (2015). Housing prices, rural-urban migrants' settlement decisions and their regional differences in China. Habitat International, 50, 149-159. doi: 10.1016/j. habitatint.2015.08.003.

25. Zhang, W.W., \& Liang, Q. (2015). Geographic concentration of labor, industrial space and regional disparities, Economics, In Qi, Y. A Study on Differences of China's Regional Economic Development Level Based on Cluster Analysis. Paper presented at the MATEC Web of Conferences. Beijing (pp. 691-708). Beijing: University of Science and Technology Beijing. (In Chin.) doi: 10.1051/ matecconf/20152205022.

26. Zhang, H.L., \& Cheng, X. (2007). The impact of intergovernmental transfer payments on local fiscal efforts and fiscal equality. Economic Science, 1, 15-23. (In Chin.) doi: 10.19523/j. jikx.2007.01.002.

\section{Information about the authors}

Lu Jia Jin - Graduate student, researcher at the Department of International Economics and management, Ural Federal University (19 Mira Str., Ekaterinburg, 620002, Russia); e-mail: lujiajin@ yandex.ru

Larisa P. Piskunova - Candidate of Philosophy, associate professor, Ural Federal University (19 Mira Str., Ekaterinburg, 620002, Russia); e-mail: reklama-urgu@yandex.ru

ARTICLE INFO: received November 11, 2020; accepted February 19, 2021

\section{Информация об авторах}

Цзяцзинь Лу - аспирант, инженер-исследователь кафедры международной экономики и менеджмента, Уральский федеральный университет (620002, Россия, г. Екатеринбург, ул. Мира, 19); e-mail: lujiajin@yandex.ru

Пискунова Лариса Петровна - доцент кафедры международной экономики и менеджмента, Уральский федеральный университет (620002, Россия, г. Екатеринбург, ул. Мира, 19); e-mail: reklama-urgu@yandex.ru

ИНФОРМАЦИЯ О СТАТЬЕ: дата поступления 11 ноября 2020 г.; дата принятия к печати 19 февраля 20212. 